\title{
Comparative Analysis of Objective Techniques for Criteria Weighing in Two MCDM Methods on Example of an Air Conditioner Selection
}

\author{
MOMČILO D. VUJIČIĆ, University of Kragujevac, \\ Faculty of Technical Sciences, Čačak \\ PAPIĆ, University of Kragujevac, \\ $M I L O S \check{Z}$. PAPIĆ, University of Kragujevac,
Faculty of Technical Sciences, Čačak \\ MARIJA D. BLAGOJEVIĆ, University of Kragujevac, \\ Faculty of Technical Sciences, Čačak
}

\author{
Professional paper \\ UDC: 005:519.226 \\ 519.816
}

DOI: 10.5937/tehnika1703422V

This paper deals with comparative analysis of two different types of objective techniques for criteria weighing: Entropy and CRITIC and two MCDM methods: MOORA and SAW on example of an air conditioner selection. We used six variants for calculation of normalized performance ratings. Results showed that the decision of the best air conditioner was basically independent of the MCDM method used, despite the applied technique for determination of criteria weights. Complete ranking within all of the combinations of methods and techniques with diverse ratio calculation variants showed that the best ranked air conditioner was A7, while the worst ones were A5 and A9. Significant positive correlation was obtained for almost all the pairs of variants in all the combinations except for the MOORA - CRITIC combination with SAW - Entropy combination to have the highest correlations between variants ( $p<$ $0.01)$.

Key words: MOORA, SAW, Entropy, CRITIC, criteria weights

\section{INTRODUCTION}

Summer temperatures in Serbia often exceed $30^{\circ}$ C. This fact other than relatively affordable prices of air conditioners for the standard of Serbian citizens, made households that do not possess air conditioners very rare. However, when selecting an air conditioner it is not all about the price. There are several criteria that must be taken into account. Therefore, this problem can be solved very efficiently by using multicriteria decision making methods.

Multi-criteria decision making (MCDM) methods have been increasingly used for quantitative evaluation of complicated economic or social processes during the recent years $[1,2,3]$.

One of the central spots in multi-criteria problems belong to criteria [4]. Taking into account the fact that the criteria weights can significantly affect the outcome of the decision making process, it is clear that special attention must be paid to the objectivity of cri

Author's address: Momčilo Vujičić, University of Kragujevac, Faculty of Technical Sciences, Čačak, Svetog Save 65, e-mail: momcilo.vujicic@ftn.kg.ac.rs

Paper received: 06.12.2016.

Paper accepted: 20.12.2016. teria weighing, which unfortunately is not always present in solving practical problems. The manner in which the weights are determined must be in accordance with the multi-criteria model to be used. Procedures for determining the weights of criteria are the subject of research and scientific debate for years. Several developed approaches for defining criteria weights can be found in literature. Basically, most approaches can be divided into subjective and objective. Objective approaches are based on the determination of criteria weights on the basis of information contained in the decision matrix by using various mathematical models. The subject of this paper is comparison of two kinds of objective techniques for defining criteria weights (Entropy and CRITIC) and their implementation in MCDM methods MOORE and SAW with comparison of six variants for the calculation of normalized performance ratings i.e. ratios within those methods, on a practical example of selecting an air conditioner.

\section{MULTI-CRITERIA DECISION MAKING METHOD}

A wide range of application areas of multi-criteria decision making models caused a rapid and continuous 
development of methods in this area. Multi-criteria method is used in wide ranges of research [5, 6, and 7]. But, in this research those methods are applied in air conditioner selection.

Therefore, there is a powerful set of methods, which are able to successfully resolve most of the real problems of multi-criteria decision making [8]. Choice of a method is often based on author's preference.

Some authors compared different methods on the same problem like Stanujkic et al. [9] who compared six MCDM methods: SAW, MOORA, GRA, CP, VIKOR and TOPSIS for ranking of banks in Serbia.

For the ranking of air conditioners in this paper, we used two multi-criteria decision making methods: MOORA (The Multi-Objective Optimization by Ratio Analysis) and SAW (Simple Additive Weighting).

\subsection{The MOORA Method}

The MOORA method (Multi-Objective Optimization on the basis of Ratio Analysis), which was first introduced in 2006 by Brauers and Zavadskas [10], is such a multi-objective (multi-criteria/multi-attribute) optimization (programming) technique that can be successfully applied into solving various types of complex decision making problems [10,11, 12].

Brauers and Zavadskas (2009) [11], concluded that the MOORA method is ready for practical use and can be a full-fledged method for multiple objective optimization.

The MOORA method consists of two components: (1) the ratio system and (2) the reference point approach. We will be dealing with the first one further on in this paper. 6 steps.

The application of the MOORA method consists of

Step 1 is to determine the objective and identify the relevant attributes of the assessment.

In this case, we considered 9 different models of air conditioners: (1) EXCLUSIVE ACS $07 \mathrm{SSH}$; (2) MIDEA MSG 12 HR; (3) VIVAX ACP-12CH35GEK; (4) GALANZ AUS-12 HR53FA2; (5) HAUSEL HAS09HM5; (6) NORDSTAR KFR-35GW; (7) NEO ACS-HH09LIH; (8) TCL TAC-12CHSA/BH and (9) SAMSUNG AQ-12FEN in terms of 5 criteria: (1) Power factor $[\cos \varphi]$, (2) Active power [kW], (3) Air flow [m3/h], (4) Price [RSD] and (5) Current [A].

Step 2 is to present all of the information available about the attributes in the form of a decision matrix (table 1), which shows performances of different alternatives in connection with different attributes. These 2 steps are fundamental in all MCDM methods.
Table 1. Decision matrix

\begin{tabular}{|c|c|c|c|c|c|c|}
\hline \multirow{4}{*}{ Alternative } & \multicolumn{5}{|l|}{ Criteria } & \\
\hline & $\mathrm{C}_{1}$ & $\mathrm{C}_{2}$ & $\mathrm{C}_{3}$ & $\ldots$ & $C_{n}$ & \\
\hline & (w1) & (w2) & (w3) & & $\left(w_{n}\right)$ & \\
\hline & $\max / \min$ & & & & & $\begin{array}{l}\text { Score } \\
\text { rank }\end{array}$ \\
\hline$A_{1}$ & $\mathrm{X}_{11}$ & $\mathrm{X}_{12}$ & $\mathrm{x}_{13}$ & $\ldots$ & $\mathrm{X} 1 \mathrm{n}$ & $\mathrm{S}_{1}$ \\
\hline $\mathrm{A}_{2}$ & $\mathrm{X}_{21}$ & $\mathrm{X}_{22}$ & $\mathrm{X}_{23}$ & $\ldots$ & $\mathrm{X} 2 \mathrm{n}$ & $\mathrm{S}_{2}$ \\
\hline : & : & : & : & $\ldots$ & : & : \\
\hline$A_{m}$ & $\mathrm{Xm} 1$ & $\mathrm{Xm}_{2}$ & $\mathrm{x}_{\mathrm{m} 3}$ & $\ldots$ & $X_{\mathrm{mn}}$ & $\mathrm{S}_{\mathrm{m}}$ \\
\hline
\end{tabular}

where $\mathrm{A} 1, \mathrm{~A} 2, \ldots, \mathrm{Am}$ is set of available alternatives, $\mathrm{C} 1, \mathrm{C} 2, \ldots, \mathrm{Cn}$ is set of criteria, w1...wn is criteria weight, xij is performance of ith alternative over jth criteria.

Step 3 is the calculation of normalized performance ratings rij (ratios) which can be performed through several existing variants:

Variant 1. Brauers and Zavadskas (2006)[10] ratios:

$$
r_{i j}=\frac{x_{i j}}{\sqrt{\sum_{i=1}^{m} x_{i j}^{2}}}
$$

where: $x i j$ is the response of alternative $\mathrm{j}$ on objective $\mathrm{i}, \mathrm{j}=1,2 \ldots, \mathrm{m} ; \mathrm{m}$ is the number of alternatives, $\mathrm{i}=1$, $2 \ldots, \mathrm{n} ; \mathrm{n}$ being the number of objectives, rij is a dimensionless number representing the normalized response of alternative $j$ on objective $i$.

Variant 2. Voogd [13] ratios:

$$
r_{i j}=\frac{x_{i j}}{\sum_{i=1}^{m} x_{i j}}
$$

Variant 3. Weitendorf [14] ratios:

$$
r_{i j}=\frac{x_{i j}-x_{j}^{\min }}{x_{j}{ }^{\max }-x_{j}^{\min }}
$$

if rij should be maximized and:

$$
r_{i j}=\frac{x_{j}{ }^{\max }-x_{i j}}{x_{j}{ }^{\max }-x_{j}{ }^{\min }}
$$

if rij should be minimized; with: and $i=1,2 \ldots, m ; j=1$, $2 \ldots, \mathrm{n}$

Variant 4. Stopp ratios:

$$
r_{i j}=\frac{x_{i j}}{x_{j} \max }
$$

if maximum rij is sought, and:

$$
r_{i j}=\frac{x_{j}^{\min }}{x_{i j}}
$$

if minimum rij is sought; where: $x_{-} j^{\wedge} \max$ represents the best value for all of the alternatives in relation with the $(C) \_j$, while $x_{-} j^{\wedge} \min$ represents the worst, with: $i=1,2 \ldots, m ; j=1,2 \ldots, n$. These normalized values are expressed in percentages. 
Variant 5. Körth (1969a, 1969b) [15, 16] ratios:

$$
r_{i j}=\frac{x_{i j}}{x_{j}^{\max }}
$$

if maximum rij is sought, and:

$$
r_{i j}=1-\frac{x_{i j}}{x_{j}^{\max }}
$$

if minimum rij is sought.

Variant 6. Peldschus et al. (1983) [17] ratios for nonlinear normalization:

$$
r_{i j}=\left(\frac{x_{i j}}{x_{i}^{\text {max }}}\right)^{2}
$$

if maximum rij is sought, and:

$$
r_{i j}=\left(\frac{x_{i}^{m i n}}{x_{i j}}\right)^{2}
$$

if minimum rij is sought.

In all the variants for ratios calculations, normalized responses of the alternatives on the objectives belong to the interval $[0 ; 1]$.

In Step 4 the normalized performances are added in the case of maximization (for desirable attributes) and subtracted in the case of minimization (for undesirable attributes). Thus, the optimization problem is solved in the following way:

$$
S_{i}=\sum_{j=1}^{g} x_{i j}-\sum_{j=g+1}^{n} x_{i j}
$$

where: $\mathrm{j}=1,2, \ldots, \mathrm{g}$ is the number of attributes to be maximized, $\mathrm{j}=\mathrm{g}+1, \mathrm{~g}+2, \ldots, \mathrm{n}$ is the number of attributes that need to be minimized, $\mathrm{Si}$ is the normalized assessment of the value of alternative $i$ in relation with other attributes.

In some cases, it can be often observed that some attributes are more important than others. In order to give more importance to a given attribute, it may be multiplied with appropriate weight (coefficient of significance). When these coefficients (attribute weights) are taken into account in relation to the previous equation, we get the following:

$$
S_{i}=\sum_{j=1}^{g} w_{j} x_{i j}-\sum_{j=g+1}^{n} w_{j} x_{i j}
$$

where: $w j$ is the weight of the $j$ th attribute $(j=1,2, \ldots$, $\mathrm{n}$ ), which can be determined by using the Analytic Hierarchy Process or Entropy method.

Step 5 is to rank alternatives and/or select the most efficient one. The considered alternatives are ranked by descending $\mathrm{Si}$, i.e., the alternatives with greater values of Si have a higher priority (rank). Determination of the most appropriate alternative $\mathrm{A}^{*}$ can be done using the following formula:

$$
\begin{aligned}
& A^{*}=\{A i \mid \text { maxiSi }\}, \text { for variants } 1 \text { and } 2 ; \\
& A^{*}=\{A i \mid \text { miniSi }\}, \text { for variants } 3,4,5 \text { and } 6
\end{aligned}
$$

\subsection{The SAW Method}

SAW (Simple Additive Weighting), which is also known as the weighted linear combination or scoring methods, is the oldest, one of the simplest, most natural and most widely used multicriteria evaluation method $[18,19]$.

The method, first utilized by Churchman and Ackoff [20], is based on the weighted average. An evaluation score is calculated for each alternative by multiplying the scaled value given to the alternative of that attribute with the weights of relative importance directly assigned by decision maker followed by summing of the products for all criteria. The advantage of this method is that it is a proportional linear transformation of the raw data, which means that the relative order of magnitude of the standardized scores remains equal [21].

The process of SAW consists of 4 steps where steps 1 to 3 are identical as in the MOORE method. Thus, steps 1 to 3 will not be discussed.

Step 4 is to evaluate each alternative Ai, Eq. (14):

$A^{*}=\max \sum_{i=1}^{m} r_{i j} w_{j}$ for variants $3,4,5$ and 6;

$A^{*}=\min \sum_{i=1}^{m} r_{i j} w_{j}$ for variants 1 and 2

where: rij is the score of the ith alternative with respect to the jth criterion, $\mathrm{wj}$ is the weighted criteria.

\section{OBJECTIVE TECHNIQUES FOR DETERMINATION OF CRITERIA WEIGHTS}

The objective approach of determining the weights of criteria, looks at the criteria as sources of information and the relative importance of the criteria reflects the amount of information contained in each one of them. The amount of information contained in each criteria is related to the intensity of the contrast of each criterion. Standard deviation and entropy are possible measures of intensity and manners of the presentation of objective criteria weight [22].

For defining weights of criteria in this paper, we will use two different objective approaches: one approach based on measuring the amount of information (Entropy) and one statistical approach (CRITIC). It should be noted that the CRITIC method generates relatively uniformed weight values which are approximate to the values of the average decision maker (DM) - equal criteria weights. That is not the case with the Entropy method, where some of the criteria are eliminated from multi-criteria evaluation [4].

Yilmaz and Harmancioglu [23] conducted the research similar to this one. Their study has delineated the best management alternative on the basis of 3 different MCDM methods (SAW, CP and TOPSIS) 
combined with 3 different techniques for criteria weighing (Entropy, CRITIC and AHP).

\subsection{Entropy Method (EM)}

Determination of objective criteria weights according to the entropy method is based on the measurement of uncertain information contained in the decision matrix and directly generates a set of weights for a given criteria based on mutual contrast of individual criteria values of variants for each criteria and then for all the criteria at the same time [4].

Determination of objective criteria weights wj according to the entropy method is carried out in three steps. Step one (Eq. 15) involves the normalization of criteria values of variants xij contained in the decision matrix (table 1):

$$
r_{i j}=\frac{x_{i j}}{\sum_{i=1}^{m} x_{i j}}
$$

This way a normalized decision matrix is obtained:

$$
\begin{aligned}
& \begin{array}{llll}
C_{1} & C_{2} & \cdots & C_{m}
\end{array} \\
& \begin{array}{llll}
w_{1} & w_{2} & \cdots & w_{m}
\end{array} \\
& =\begin{array}{c}
A_{1} \\
A_{2} \\
\cdots \\
A_{n}
\end{array}\left[\begin{array}{cccc}
a_{11} & a_{12} & \cdots & a_{1 m} \\
a_{21} & a_{22} & \cdots & a_{2 m} \\
\cdots & \cdots & \cdots & \cdots \\
a_{n 1} & a_{n 2} & \cdots & a_{n m}
\end{array}\right]
\end{aligned}
$$

The information contained in matrix $\mathrm{R}$ can be considered as the "emission power" of each criterion $\mathrm{Cj}$ and is used to compute an entropy value ej:

$$
e_{j}=-k \sum_{i=1}^{m} r_{i j} \ln r_{i j}
$$

a constant $\mathrm{k}, \mathrm{k}=1 / \mathrm{ln} \mathrm{n}$, is used to guarantee that $\mathrm{ej}(\mathrm{j}=1$, $2 \ldots, n)$ belongs to the interval $[0 ; 1]$.

The degree of divergence $(\mathrm{dj})$ of the average intrinsic information contained in each criteria is calculated as:

$$
d_{j}=1-e_{j}
$$

where: $d j(j=1,2 \ldots, n)$ is inherent intensity of criteria contrast $\mathrm{Cj}$.

Since the value of $\mathrm{dj}$ is a specific measure of the intensity of a criteria contrast $\mathrm{Cj}$, the final relative weight of the criteria, in the third step of the method, can be obtained by the simple additive normalization:

$$
w_{j}=\frac{d_{j}}{\sum_{j=1}^{n} d_{j}}
$$

The method can be regarded as an objective while it generates weighted criteria values directly from the criteria value variations and eliminates the problem of subjectivity, incompetence or absence of decisionmakers.

Also, either the type or the nature of the criteria is not important and does not matter.

\subsection{CRITIC Method (CM)}

The CRITIC method (CRiteria Importance Through Intercriteria Correlation) [24] belongs to the class of correlation methods. It is based on analytical testing of the decision matrix in order to determine the information contained in the criteria by which variants are evaluated.

For each criteria xij membership function rij which translates all the values of criteria fj into interval $[0,1]$, is defined.

$$
r_{i j}=\frac{x_{i j}-x_{j}^{\min }}{x_{j}{ }^{\max }-x_{j}{ }^{\min }}
$$

This transformation is based on the concept of an ideal point. In this way, the initial matrix is converted into a matrix with generic elements rij.

Each vector has a standard deviation, which represents the degree of deviation of variant values for a given criteria of a mean value. The amount of information $\mathrm{C} j$ contained in the criteria $\mathrm{j}$ is determined in the following manner:

$$
C_{j}=\sigma_{j} \sum_{i=1}^{m}\left(1-r_{i j}\right)
$$

Objective criteria weights are obtained by normalizing the values $\mathrm{Cj}$ :

$$
w_{j}=\frac{C_{j}}{\sum_{i=1}^{m} C_{i}}
$$

\begin{tabular}{|c|c|c|c|c|c|}
\hline \multirow{3}{*}{ 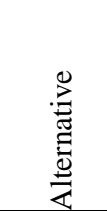 } & \multicolumn{5}{|l|}{ Criteria } \\
\hline & $\mathrm{f} 1$ & $\mathrm{f} 2$ & f3 & $\mathrm{f} 4$ & $\mathrm{f} 5$ \\
\hline & $\begin{array}{l}\text { Power } \\
\text { factor (cos) }\end{array}$ & $\begin{array}{l}\text { Active } \\
\text { power }(\mathrm{kW})\end{array}$ & \begin{tabular}{|l} 
Air \\
Flow \\
$\left(\mathrm{m}^{3} / \mathrm{h}\right)$
\end{tabular} & $\begin{array}{l}\text { Price } \\
\text { (rsd) }\end{array}$ & Current (A) \\
\hline $\max / \min$ & $\max$ & $\min$ & $\max$ & $\min$ & $\min$ \\
\hline $\mathrm{a} 1$ & 0.87356 & 0.62176470 & 6520 & 25000 & 3.160588 \\
\hline $\mathrm{a} 2$ & 0.900285714 & 0.789785714 & 550 & 27500 & 4.082143 \\
\hline a3 & 0.911652 & 0.577609 & 550 & 31500 & 2.815217 \\
\hline a4 & 0.95144 & 0.82989 & 450 & 28500 & 3.855556 \\
\hline a5 & 0.808 & 0.837652 & 530 & 26000 & 4.617391 \\
\hline a6 & 0.947846 & 0.636308 & 600 & 30500 & 3.006154 \\
\hline a7 & 0.95008 & 0.50583 & 530 & 24500 & 2.369167 \\
\hline $\mathrm{a} 8$ & 0.9325 & 0.788917 & 530 & 26450 & 3.841667 \\
\hline a9 & 0.930615 & 0.791615 & 750 & 35000 & 3.863077 \\
\hline
\end{tabular}

\subsection{Case study}

Table 2 represents the so-called decision matrix or evaluation table for the defined scenario (selection of an air conditioner), and consists of five criteria (power factor, active power, air flow, price and current) and 9 alternatives is different air conditioner brands, where air conditioners are not sorted as they were previously (Step 1 - page 2).

Table 2. Decision matrix with the data on air conditioners 
Criteria weights will be defined by using Entropy and CRITIC methods and alternatives will then be ranked by using MOORA and SAW methods with six above mentioned variants.

\subsection{Criteria Weights Obtained by the Entropy \\ Method}

Decision matrix R, normalized by Eq. (15) is shown in Table 3.

Table 3. Normalized decision matrix $R$

\begin{tabular}{|l|r|r|r|r|l|}
\hline & $\mathrm{r} 1$ & $\mathrm{r} 2$ & $\mathrm{r} 3$ & $\mathrm{r} 4$ & \multicolumn{1}{|c|}{$\mathrm{r} 5$} \\
\hline $\mathrm{a} 1$ & 0.106 & 0.097 & 0.104 & 0.098 & 0.100 \\
\hline $\mathrm{a} 2$ & 0.110 & 0.124 & 0.110 & 0.108 & 0.129 \\
\hline $\mathrm{a} 3$ & 0.111 & 0.091 & 0.110 & 0.124 & 0.089 \\
\hline $\mathrm{a} 4$ & 0.116 & 0.130 & 0.090 & 0.112 & 0.122 \\
\hline $\mathrm{a} 5$ & 0.098 & 0.131 & 0.106 & 0.102 & 0.146 \\
\hline $\mathrm{a} 6$ & 0.116 & 0.100 & 0.120 & 0.120 & 0.095 \\
\hline $\mathrm{a} 7$ & 0.116 & 0.079 & 0.106 & 0.096 & 0.075 \\
\hline $\mathrm{a} 8$ & 0.114 & 0.124 & 0.106 & 0.104 & 0.122 \\
\hline $\mathrm{a} 9$ & 0.113 & 0.124 & 0.150 & 0.137 & 0.122 \\
\hline
\end{tabular}

According to Eq. (17, 18 and 19) respectively, the values of entropy (ej), the degree of divergence (dj), and the relative weight of criteria (wj) were obtained (Table 4).

Table 4. Entropy, degree of divergence and the relative weight of criteria

\begin{tabular}{|l|l|l|l|l|l|}
\hline \multirow{5}{*}{} & \multicolumn{4}{l}{ Criteria } & \multicolumn{4}{l|}{} \\
\cline { 2 - 6 } & $\mathrm{f} 1$ & $\mathrm{f} 2$ & $\mathrm{f3}$ & $\mathrm{f} 4$ & $\mathrm{f5}$ \\
\hline $\mathrm{e}_{\mathrm{j}}$ & 0.999 & 0.994 & 0.996 & 0.997 & 0.991 \\
\hline $\mathrm{d}_{\mathrm{j}}$ & 0.001 & 0.006 & 0.004 & 0.003 & 0.009 \\
\hline $\mathrm{w}_{\mathrm{j}}$ & 0.024 & 0.282 & 0.186 & 0.129 & 0.378 \\
\hline
\end{tabular}

\subsection{Criteria Weights Obtained by the Critic Method}

Decision matrix R, normalized by Eq. (20) is shown in Table 5.

Table 5. Normalized decision matrix $R$

\begin{tabular}{|l|r|r|r|r|l|}
\hline & $\mathrm{r} 1$ & $\mathrm{r} 2$ & $\mathrm{r} 3$ & $\mathrm{r} 4$ & \multicolumn{1}{|c|}{$\mathrm{r} 5$} \\
\hline $\mathrm{a} 1$ & 0.457 & 0.349 & 0.233 & 0.048 & 0.352 \\
\hline $\mathrm{a} 2$ & 0.643 & 0.856 & 0.333 & 0.286 & 0.762 \\
\hline $\mathrm{a} 3$ & 0.723 & 0.216 & 0.333 & 0.667 & 0.198 \\
\hline $\mathrm{a} 4$ & 1.000 & 0.977 & 0.000 & 0.381 & 0.661 \\
\hline $\mathrm{a} 5$ & 0.000 & 1.000 & 0.267 & 0.143 & 1.000 \\
\hline $\mathrm{a} 6$ & 0.975 & 0.393 & 0.500 & 0.571 & 0.283 \\
\hline $\mathrm{a} 7$ & 0.991 & 0.000 & 0.267 & 0.000 & 0.000 \\
\hline $\mathrm{a} 8$ & 0.868 & 0.853 & 0.267 & 0.186 & 0.655 \\
\hline $\mathrm{a} 9$ & 0.855 & 0.861 & 1.000 & 1.000 & 0.664 \\
\hline
\end{tabular}

The amount of information $\mathrm{Cj}$ contained in criteria $\mathrm{j}$ and criteria weights (wj) were obtained according to Eq. (21 and 22) respectively (Table 6).

Table 6. The amount of information and criteria weights

\begin{tabular}{|l|l|l|l|l|l|}
\hline \multirow{2}{*}{} & \multicolumn{5}{|l|}{ Criteria } \\
\cline { 2 - 6 } & $\mathrm{f} 1$ & $\mathrm{f} 1$ & $\mathrm{f} 1$ & $\mathrm{f} 1$ & $\mathrm{f} 1$ \\
\hline $\mathrm{C}_{\mathrm{j}}$ & 1.810542 & 1.474244 & 1.063343 & 1.132035 & 1.401902 \\
\hline $\mathrm{w}_{\mathrm{j}}$ & 0.263081 & 0.214215 & 0.154509 & 0.164491 & 0.203704 \\
\hline
\end{tabular}

\section{RESULTS}

Complete ranking of alternatives (air conditioners) according to 6 variants for both MOORA and SAW using both Entropy and CRITIC for defining weights of criteria, is shown in tables $7 a-8 b$.

Table 7a. Complete ranking of alternatives obtained by MOORA - Entropy

\begin{tabular}{|c|c|c|c|c|c|c|c|c|c|c|c|}
\hline Weights & MOORA & \multicolumn{10}{|c|}{ Air conditioner } \\
\hline \multirow{6}{*}{ ENTROPY } & Variant 1 & 4 & 7 & 2 & 8 & 9 & 3 & 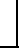 & 6 & 5 & \multirow{7}{*}{ Rank } \\
\hline & Variant 2 & 4 & 7 & 2 & 8 & 9 & 3 & & 6 & 5 & \\
\hline & Variant 3 & 2 & 7 & 3 & 6 & 8 & 2 & & 5 & 9 & \\
\hline & Variant 4 & 3 & 7 & 2 & 5 & 8 & 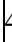 & & 6 & 9 & \\
\hline & Variant 5 & 3 & 7 & 2 & 6 & 8 & 2 & & 5 & 9 & \\
\hline & Variant 6 & 3 & 7 & 2 & 6 & 8 & & 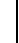 & 5 & 9 & \\
\hline Alternatives & & a1 & $\mathrm{a} 2$ & a3 & $\mathrm{a} 4$ & as & $a^{a}$ & & 17 a8 & a9 & \\
\hline
\end{tabular}

Table $7 b$. Complete ranking of alternatives obtained by MOORA - CRITIC

\begin{tabular}{|c|c|c|c|c|c|c|c|c|c|c|c|}
\hline Weights & MOORA & \multicolumn{10}{|c|}{ Air conditioner } \\
\hline \multirow{6}{*}{ CRITIC } & Variant 1 & 4 & 7 & 3 & 8 & 9 & 2 & 1 & 6 & 5 & \multirow{7}{*}{ Rank } \\
\hline & Variant 2 & 4 & 7 & 3 & 8 & 9 & 2 & 1 & 6 & 5 & \\
\hline & Variant 3 & 2 & 6 & 3 & 8 & 4 & 5 & 1 & 7 & 9 & \\
\hline & Variant 4 & 2 & 8 & 3 & 7 & 5 & 4 & 1 & 6 & 9 & \\
\hline & Variant 5 & 2 & 7 & 3 & 8 & 4 & 5 & 1 & 6 & 9 & \\
\hline & Variant 6 & 2 & 8 & 3 & 6 & 7 & 4 & 1 & 5 & 9 & \\
\hline Alternativ & & a1 & $\mathrm{a} 2$ & a3 & a4 & a5 & a6 & a7 & a8 & a9 & \\
\hline
\end{tabular}

Table 8a. Complete ranking of alternatives obtained by SAW-Entropy

\begin{tabular}{|c|c|c|c|c|c|c|c|c|c|c|c|}
\hline Weights & SAW & \multicolumn{10}{|c|}{ Air conditioner } \\
\hline \multirow{6}{*}{ ENTROPY } & Variant 1 & & 7 & 2 & 6 & 8 & 4 & 1 & 5 & 9 & \multirow{7}{*}{ Rank } \\
\hline & Variant 2 & 3 & 7 & 2 & 6 & 8 & 4 & 1 & 5 & 9 & \\
\hline & Variant 3 & 4 & 7 & 2 & 8 & 9 & 3 & 1 & 6 & 5 & \\
\hline & Variant 4 & 4 & 7 & 2 & 8 & 9 & 3 & 1 & 6 & 5 & \\
\hline & Variant 5 & 4 & 7 & 2 & 8 & 9 & 3 & 1 & 6 & 5 & \\
\hline & Variant 6 & 4 & 7 & 2 & 8 & 9 & 3 & 1 & 6 & 5 & \\
\hline Alternatives & & a1 & $\mathrm{a} 2$ & a3 & a4 & a5 & a6 & a7 & a8 & a9 & \\
\hline
\end{tabular}


Table $8 b$. Complete ranking of alternatives obtained by SAW - CRITIC

\begin{tabular}{|c|c|c|c|c|c|c|c|c|c|c|c|}
\hline Weights & SAW & \multicolumn{10}{|c|}{ Air conditioner } \\
\hline \multirow{6}{*}{ CRITIC } & Variant 1 & & 7 & 3 & 6 & 8 & 4 & 1 & 5 & 9 & \multirow{7}{*}{ Rank } \\
\hline & Variant 2 & & 7 & 3 & 6 & 8 & 4 & 1 & 5 & 9 & \\
\hline & Variant 3 & & 8 & 3 & 7 & 9 & 2 & 1 & 5 & 6 & \\
\hline & Variant 4 & & 7 & 2 & 8 & 9 & 3 & 1 & 6 & 5 & \\
\hline & Variant 5 & & 7 & 3 & 8 & 9 & 2 & 1 & 6 & 5 & \\
\hline & Variant 6 & 4 & 7 & 2 & 8 & 9 & 3 & 1 & 6 & 5 & \\
\hline Alternati & & a1 & $\mathrm{a} 2$ & a3 & a4 & as & $\mathrm{at}$ & a7 & $a 8$ & a9 & \\
\hline
\end{tabular}

It can be concluded that in all the combinations of MCDM methods and objective techniques for defining criteria weights, air conditioner A7, proved to be the best alternative, while the worst ones were air conditioners A5 and A9.

\subsection{Correlations between variants}

The Pearson correlation coefficient $r$ for all pairs of six variants for all combinations of MCDM methods and objective techniques for defining criteria weights is shown in tables $9 \mathrm{a}-9 \mathrm{~d}$.

Table 9a. Pearson correlations between variants for MOORA - Entropy combination

\begin{tabular}{|l|l|l|l|l|l|l|}
\hline & $\begin{array}{l}\text { Variant } \\
1\end{array}$ & $\begin{array}{l}\text { Variant } \\
2\end{array}$ & $\begin{array}{l}\text { Variant } \\
\text { Variant }\end{array}$ & $\begin{array}{l}\text { Variant } \\
5\end{array}$ & $\begin{array}{l}\text { Variant } \\
6\end{array}$ \\
\hline Variant 1 & 1 & $1.000^{* * *}$ & $0.767^{*}$ & $0.767^{*}$ & $0.800^{* *}$ & $0.800^{* *}$ \\
\hline Variant 2 & & 1 & $0.767^{*}$ & $0.767^{*}$ & $0.800^{* *}$ & $0.800^{* *}$ \\
\hline Variant 3 & & & 1 & $0.967^{* *}$ & $0.983^{* *}$ & $0.983^{* *}$ \\
\hline Variant 4 & & & & 1 & $0.983^{* *}$ & $0.983^{* *}$ \\
\hline Variant 5 & & & & & 1 & $1.000^{* *}$ \\
\hline Variant 6 & & & & & & 1 \\
\hline
\end{tabular}

Table 9b. Pearson correlations between variants for MOORA - CRITIC combination

\begin{tabular}{|l|l|l|l|l|l|l|}
\hline & $\begin{array}{l}\text { Variant } \\
1\end{array}$ & $\begin{array}{l}\text { Variant } \\
2\end{array}$ & $\begin{array}{l}\text { Varian } \\
\mathrm{t} 3\end{array}$ & $\begin{array}{l}\text { Variant } \\
4\end{array}$ & $\begin{array}{l}\text { Variant } \\
5\end{array}$ & $\begin{array}{l}\text { Variant } \\
6\end{array}$ \\
\hline Variant 1 & 1 & $1.000^{* *}$ & 0.533 & 0.650 & 0.550 & $0.717^{*}$ \\
\hline Variant 2 & & 1 & 0.533 & 0.650 & 0.550 & $0.717^{*}$ \\
\hline Variant 3 & & & 1 & $0.933^{* *}$ & $0.983^{* *}$ & $0.817^{* *}$ \\
\hline Variant 4 & & & & 1 & $0.967^{* *}$ & $0.950^{* *}$ \\
\hline Variant 5 & & & & & 1 & $0.867^{* *}$ \\
\hline Variant 6 & & & & & & 1 \\
\hline
\end{tabular}

Table 9c. Pearson correlations between variants for SAW - Entropy combination

\begin{tabular}{|l|l|l|l|l|l|l|}
\hline & $\begin{array}{l}\text { Variant } \\
1\end{array}$ & $\begin{array}{l}\text { Variant } \\
2\end{array}$ & $\begin{array}{l}\text { Variant } \\
3\end{array}$ & $\begin{array}{l}\text { Varian } \\
\mathrm{t} 4\end{array}$ & $\begin{array}{l}\text { Variant } \\
5\end{array}$ & $\begin{array}{l}\text { Variant } \\
6\end{array}$ \\
\hline Variant 1 & 1 & $1.000^{* *}$ & $0.800^{* *}$ & $0.800^{* *}$ & $0.800^{* *}$ & $0.800^{* *}$ \\
\hline Variant 2 & & 1 & $0.800^{* *}$ & $0.800^{* *}$ & $0.800^{* *}$ & $0.800^{* *}$ \\
\hline Variant 3 & & & 1 & $1.000^{* *}$ & $1.000^{* *}$ & $1.000^{* *}$ \\
\hline Variant 4 & & & & 1 & $1.000^{* *}$ & $1.000^{* *}$ \\
\hline Variant 5 & & & & & 1 & $1.000^{* *}$ \\
\hline Variant 6 & & & & & & 1 \\
\hline
\end{tabular}

Table 9d. Pearson correlations between variants for SAW - CRITIC combination

**. Correlations are significant at the 0.01 level

*. Correlations are significant at the 0.05 level

\begin{tabular}{|l|l|l|l|l|l|l|}
\hline & $\begin{array}{l}\text { Variant } \\
1\end{array}$ & $\begin{array}{l}\text { Variant } \\
2\end{array}$ & $\begin{array}{l}\text { Variant } \\
3\end{array}$ & $\begin{array}{l}\text { Variant } \\
4\end{array}$ & $\begin{array}{l}\text { Variant } \\
5\end{array}$ & $\begin{array}{l}\text { Variant } \\
6\end{array}$ \\
\hline Variant 1 & 1 & $1.000^{* *}$ & $0.833^{* *}$ & $0.767^{*}$ & $0.750^{*}$ & $0.767^{*}$ \\
\hline Variant 2 & & 1 & $0.833^{* *}$ & $0.767^{*}$ & $0.750^{*}$ & $0.767^{*}$ \\
\hline Variant 3 & & & 1 & $0.950^{* *}$ & $0.967^{* *}$ & $0.950^{* *}$ \\
\hline Variant 4 & & & & 1 & $0.983^{* *}$ & $1.000^{* *}$ \\
\hline Variant 5 & & & & & 1 & $0.983^{* *}$ \\
\hline Variant 6 & & & & & & 1 \\
\hline
\end{tabular}

Statistically significant positive correlation was found in almost all of the cases, except for 6 pairs of variants in the MOORA - CRITIC combination (1$3 ; 1-4 ; 1-5 ; 2-3 ; 2-4$ and 2-5). The highest correlations between variants $(\mathrm{p}<0.01)$ were found in the SAW - Entropy combination. There were 7 perfect correlations in this combination and 5 in all other combinations together.

\section{CONCLUSION}

Selection of the optimal air conditioner, defined through 5 criteria, using MCDM methods MOORA and SAW in combination with two different types of objective techniques of criteria weighing Entropy and CRITIC showed that the decision of the best alternative (air conditioner) was basically independent from the MCDM method used, although different approaches for defining criteria weights, as expected, gave different results.

Complete ranking of the alternatives in all the method - technique - ratio variant combinations showed that the air conditioner A7 was the best solution while the worst ones were air conditioners A5 and $\mathrm{A} 9$.

Significant positive correlation was obtained for almost all the pairs of variants in all the combinations except for the MOORA - CRITIC combination.

\section{REFERENCES}

[1] Doukas H, Patlitzianas K. D, \& Psarras J, Supporting sustainable electricity technologies in Greece using MCDM. Resources Policy, Vol. 31, No. 2, pp. 129136. doi:10.1016/j.resourpol.2006.09.003, 2006.

[2] Chatterjee P, \& Chakraborty, S. Material selection using preferential ranking methods. Materials \& Design, Vol. 35, pp. 384-393. doi:10.1016/j.matdes.2011.09.027, 2012.

[3] Bozanic, D., Pamucar, D., \& Bojanic, D. Modification of the analytic hierarchy process (AHP) method using fuzzy logic: Fuzzy AHP approach as a support 
to the decision making process concerning engagement of the group for additional hindering. Serb $J$ Management Serbian Journal of Management, Vol. 10, No. 2, pp. 151-171. doi:10.5937/sjm10-7223, 2015.

[4] Srđević B, Medeiros Y, Faria A, \& Schaer M, Objective Evaluation of Performance Criteria for a Reservoir System, Vodoprivreda, Vol. 35, No. (3-4), pp. 163-176. 2003.

[5] Vuković D, Višekriterijumski izbor podsistema JGTP od strane društvene zajednice - studija slučaja 'Beovoz', Tehnika, Vol. 69, No. 1, pp. 121-126. 2014.

[6] Popović Ž, Stanković J, \& Veselinović I, Uticaj subjektivnih preferencija na proces odlučivanja $\mathrm{u}$ višekriterijumskom modelu javnih nabavki, Tehnika, Vol. 39, No. 2, pp. 307-326. 2015.

[7] Kuzovič Lj, Aleksić B, \& Glavić D, Primena višekriterijumske analize $\mathrm{u}$ vrednovanju projekata puteva, Tehnika, Vol. 70, No. 1, pp. 143-150. 2015.

[8] Čupić M, \& Suknović M, Odlučivanje, Fakultet organizacionih nauka, Beograd, 2010.

[9] Stanujkić D, Đorđević B, \& Đorđević M, Comparative analysis of some prominent MCDM methods: A case of ranking Serbian banks. Serbian Journal of Management, Vol. 8, No. 2, pp. 213-241. doi:10.5937/sjm8-3774, 2013.

[10]Brauers W. K. M, \& Zavadskas E. K, The MOORA method and its application to privatization in a transition economy, Control and Cybernetics, Vol. 35, No. 2, pp. 445-469. 2006.

[11]Brauers W. K, \& Zavadskas E. K, Robustness of the multi-objective MOORA method with a test for the facilities sector. Technological and Economic Development of Economy, Vol. 15, No. 2, pp. 352375. doi:10.3846/1392-8619.2009.15.352-375, 2009.

[12]Chakraborty S, Applications of the MOORA method for decision making in manufacturing environment. The International Journal of Advanced Manufacturing Technology Int J Adv Manuf Technol, Vol. 54, No. (9-12), 1155-1166. doi:10.1007/s00170-0102972-0, 2010.

[13]Voogd H, Multicriteria Evaluation for Urban and Regional Planning, Pion ltd., London, 1983.

[14]Weitendorf D, Beitrag zur Optimierung der räumlichen Struktur eines Gebäude, Dissertation A, Hochschule für Architektur und Bauwesen, Weimar, 196.
[15]Körth H, Zur Berücksichtigung mehrerer Zielfunktionen bei der Optimierung von Produktionsplänen, Mathematik und Wirtschaft, Vol. 6, pp. 184-201. 1969.

[16]Körth H, Untersuchungen zur nichtlinearen Optimierung ökonomischer Erscheinungen und Prozesse unter besonderer Berücksichtigung der Quoitientenoptimierung sowie der Lösung ökonomischer mathematischer Modelle bei Existenz mehrerer Zielfuntionen, Habilitationsschrift Humboldt, Universität Sektion Wirtschaftswissenschaften, Berlin, 1969.

[17]Peldschus, F. Zur Anwendung der Theorie der Spiele für Aufgaben der Bautechnologie, Dissertation B, TH Leipzig, 1986.

[18]Podvezko, V. The Comparative Analysis of MCDA Methods SAW and COPRAS. Engineering Economics EE, Vol. 22, No. 2, doi:10.5755/j01.ee.22.2.310, 2011.

[19]Parvesh A, \& Mohit S, Performance Measurement of an Industry Using Simple Additive Weightage, International Journal for Research in Applied Science and Engineering Technology, Vol. 1, No. 3, pp. 1-3. 2013.

[20]Churchman C.W, \& Ackoff R.L, An approximate measure of value, Journal of Operations Research Society of America, Vol. 2, No. 1, pp. 172-187. 1954.

[21]Afshari A, Mojahed M, \& Yusuff R. M, Simple Additive Weighting approach to Personnel Selection problem, International Journal of Innovation, Management and Technology, Vol. 1, No. 5, pp. 511515. 2010.

[22]Zeleny M Multiple criteria decision making. New York: McGraw-Hill, 1982.

[23]Yilmaz B, \& Harmancioglu N, Multi-criteria decision making for water resource management: A case study of the Gediz River Basin, Turkey. Water SA WSA, Vol. 36, No. 5, doi:10.4314/wsa.v36i5.61990, 2010.

[24]Diakoulaki D, Mavrotas G, \& Papayannakis L, Determining objective weights in multiple criteria problems: The critic method, Computers \& Operations Research, Vol. 22, No. 7, pp. 763-770. doi:10.1016/0305-0548(94)00059-h, 1995. 


\section{REZIME}

\section{UPOREDNA ANALIZA OBJEKTIVNIH TEHNIKA ZA ODREĐIVANJE TEŽINA KRITERIJUMA U DVE METODE VIŠEKRITERIJUMSKOG ODLUČIVANJA NA PRIMERU IZBORA KLIMA UREĐAJA}

Ovaj rad se bavi komparativnom analizom dve različite vrste objektivnih tehnika za određivanje težina kriterijuma: Entropija i CRITIC primenjenih u dve metode višekriterijumskog odlučivanja: MOORA $i$ SAW na primeru selekcije klima uređaja. Korišćeno je šest varijanti za računanje normalizovanih kriterijumskih vrednosti (racia). Rezultati su pokazali da je odluka o najboljem klima uređaju u osnovi nezavisna od primenjenih metoda, uprkos primenjenim tehnikama za određivanje težina kriterijuma. Kompletno rangiranje u svim kombinacijama metoda i tehnika sa različitim načinima računanja racia pokazalo je da je najbolje rangirana alternativa klima uređaj A7, a najlošije su bile A5 i A9. Značajna pozitivna korelacija je dobijena za skoro sve parove varijanti u svim kombinacijama osim za MOORACRITIC kombinaciju pri čemu je kombinacija SAW - Entropija imala najveću korelaciju između varijanti $(p<0.01)$.

Ključne reči: MOORA, SAW, Entropija, CRITIC, težine kriterijuma 